\title{
The Effect of Consumer-Based Brand Equity and Satisfaction on Loyalty: An Empirical Study
}

\author{
Muhammad Adreaginola Pratama ${ }^{1}$, Rizki Pratama Saleh Siregar ${ }^{2}$, \\ Sabrina Oktaria Sihombing ${ }^{3^{*}}$ \\ 1,2,3 Universitas Pelita Harapan, Indonesia \\ 1andreginola@yahoo.com, ${ }^{2}$ rizky30@yahoo.com, ${ }^{3}$ sabrina.sihombing@uph.edu, ${ }^{*}$ corresponding author
}

\begin{abstract}
Economic growth in Indonesia encourages the growth of many industries. Specifically, the food and beverage industry has grown significantly in Indonesian economics. Coffee shops with foreign or local brands are growing and competing for having customer loyalty. Many research has been conducted to examine customer loyalty in a particular coffee shop. However, little research has been focused on comparing both local and foreign brand names of the coffee shop. The comparative study is needed to understand whether foreign or local brand names matter in predicting both customer satisfaction and loyalty. This research uses a quantitative paradigm using descriptive research type. The object of research is Starbucks (foreign brand) and Djournal Coffee (local brand). Data were collected through questionnaires distributed by applying judgemental sampling. Data analysis was conducted by using structural equation model (SEM). In this study, there are two unsupported hypotheses namely (1) the relationship between the ideal self-congruence and customer satisfaction, and (2) the relationship between brand identification and customer satisfaction. The study also provides theoretical contributions, managerial implications and suggestions for further research.
\end{abstract}

Keywords: brand equity, customer satisfaction, brand loyalty, SEM

\section{Pengaruh Ekuitas Merek Berbasis Konsumen dan Kepuasan terhadap Loyalitas: Sebuah Studi Empiris}

\begin{abstract}
Abstrak: Pertumbuhan ekonomi di Indonesia mendorong pertumbuhan banyak industri. Secara khusus, industri makanan dan minuman telah tumbuh secara signifikan dalam ekonomi Indonesia. Kedai kopi dengan merek asing atau lokal tumbuh dan bersaing untuk memiliki loyalitas pelanggan. Banyak penelitian telah dilakukan untuk menguji loyalitas pelanggan di coffee shop tertentu. Namun, sedikit penelitian yang difokuskan untuk membandingkan nama merek lokal dan asing dari coffee shop. Studi perbandingan diperlukan untuk memahami apakah nama merek asing atau lokal penting dalam memprediksi kepuasan dan loyalitas pelanggan. Penelitian ini menggunakan paradigma kuantitatif dengan menggunakan tipe penelitian deskriptif. Objek penelitian adalah Starbucks (merek asing) dan Djournal Coffee (merek lokal). Data dikumpulkan melalui kuesioner yang didistribusikan dengan menggunakan judgemental sampling. Analisis data dilakukan dengan menggunakan pemodelan persamaan struktural (SEM). Dalam penelitian ini ada dua hipotesis yang tidak didukung yaitu (1) hubungan antara kongruensi diri yang ideal dan kepuasan pelanggan dan (2) hubungan antara identifikasi merek dan kepuasan pelanggan. Studi ini juga memberikan kontribusi teoritis, implikasi manajerial dan saran untuk penelitian lebih lanjut.
\end{abstract}

Kata kunci: ekuitas merek, kepuasan konsumen, loyalitas merek, SEM

\section{PENDAHULUAN}

Food and beverage industry continues to grow in Indonesia. Data provided by the Ministry of Culture and Trade on the Association of Indonesian Food and Beverage Entrepreneurs (GAPMMI) stated that the national food and beverage industry continued to show positive performance by growing to $9,82 \%$ or Rp192.69 trillion in the third quarter of 2016 . Specifically, food and beverage industries in Indonesia in recent years are coffee and coffee processing products that show an increase every year (Rasmikayati et al., 2017). 
Table 1. Research of coffee shops loyalty

\begin{tabular}{|c|c|c|c|c|c|}
\hline \multirow[t]{2}{*}{ No } & \multirow[t]{2}{*}{ Researcher (Year) } & \multirow{2}{*}{$\begin{array}{l}\text { Research } \\
\text { location }\end{array}$} & \multicolumn{2}{|c|}{ Comparison } & \multirow{2}{*}{$\begin{array}{l}\text { Brands } \\
\text { applied }\end{array}$} \\
\hline & & & No & Yes & \\
\hline 1. & $\begin{array}{l}\text { Amanata et al. } \\
(2017)\end{array}$ & Indonesia & $\sqrt{ }$ & & Starbucks \\
\hline 2. & $\begin{array}{l}\text { Andreani et al. } \\
\text { (2017) }\end{array}$ & Indonesia & $\sqrt{ }$ & & Starbucks \\
\hline 3. & Anggraeni (2014) & Indonesia & $\sqrt{ }$ & & $\begin{array}{l}\text { Coffee } \\
\text { Toffee }\end{array}$ \\
\hline 4. & $\begin{array}{l}\text { Budiman et al. } \\
\text { (2013) }\end{array}$ & Indonesia & $\sqrt{ }$ & & Starbucks \\
\hline 5. & $\begin{array}{l}\text { Hadiwidjaja and } \\
\text { Dharmayanti } \\
(2015)\end{array}$ & Indonesia & $\sqrt{ }$ & & Starbucks \\
\hline 6. & Kristanto (2015) & Indonesia & $\sqrt{ }$ & & $\begin{array}{l}\text { D'Cooffe } \\
\text { Coffee }\end{array}$ \\
\hline 7. & $\begin{array}{l}\text { Larasati and } \\
\text { Suryaputra (2013) }\end{array}$ & Indonesia & $\sqrt{ }$ & & $\begin{array}{l}\text { Coffee } \\
\text { Toffee }\end{array}$ \\
\hline 8. & $\begin{array}{l}\text { Leha and Subagyo } \\
\text { (2014) }\end{array}$ & Indonesia & $\sqrt{ }$ & & Starbucks \\
\hline 9. & Novia et al. (2016) & Indonesia & $\sqrt{ }$ & & Starbucks \\
\hline 10. & Prasetya (2015) & Indonesia & $\sqrt{ }$ & & $\begin{array}{l}\text { Just } \\
\text { Coffee }\end{array}$ \\
\hline 11. & $\begin{array}{l}\text { Rorimpandey et } \\
\text { al. }(2017)\end{array}$ & Indonesia & $\sqrt{ }$ & & $\begin{array}{l}\text { Black Cup } \\
\text { Coffee }\end{array}$ \\
\hline 12. & $\begin{array}{l}\text { Saraswati et al. } \\
(2014)\end{array}$ & Indonesia & $\sqrt{ }$ & & Starbucks \\
\hline 13. & $\begin{array}{l}\text { Susanty and } \\
\text { Kenny (2015) }\end{array}$ & Indonesia & & $\sqrt{ }$ & $\begin{array}{l}\text { Starbucks } \\
\text { dan } \\
\text { Excelso }\end{array}$ \\
\hline 14. & $\begin{array}{l}\text { Senjaya et al. } \\
(2013)\end{array}$ & Indonesia & $\sqrt{ }$ & & Starbucks \\
\hline 15. & $\begin{array}{l}\text { Setiadi, Djoko } \\
\text { and Ngatno } \\
(2015)\end{array}$ & Indonesia & $\sqrt{ }$ & & $\begin{array}{l}\text { J.co } \\
\text { Coffee }\end{array}$ \\
\hline
\end{tabular}

Source: summarized from previous research cited above

The number of coffee shop in Indonesia is significantly growing can be seen from the number of coffee shops that do the franchise or open the coffee shop by using a new brand. Coffee shop business in Indonesia began since the inclusion of a coffee shop company originating from Seattle, United States that is Starbucks. Starbucks coffee shops change people's perceptions of consuming coffee including in Indonesia, because Starbucks provides adequate facilities at its coffee shop for the convenience of its customers since customers come to coffee shops not just to drink coffee only, but to relax enjoy the environment, meet colleagues or take a break from a tiring day. What Starbucks does get a positive response from its loyal customers, because a competitive advantage is born when all parties in the company hold that there is nothing trivial and customers pay attention to 
everything. Therefore, many emerging local coffee shops by following the concept of Starbucks to compete and create satisfaction experienced by customers to gain loyalty from them. But little research on brand loyalty in coffee shops by comparing foreign and local brands of coffee shops (Table 1). With reference to research gap, this research aims to compare two brands of foreign and local coffee shops in examining the relationship of brand equity and customer satisfaction with brand loyalty.

Business needs a physical facility to support the business activity. Physical quality is defined as an environment that covers the overall layout, ambiance, design, lighting, decoration and aesthetics of a restaurant/cafe (Lee \& Jeong, 2012). Furthermore, the physical environment is considered as an important factor for the success of any restaurant/cafe. Especially for business services that are intangible and require the role of customers during the process takes place. Furthermore, many companies increase customer satisfaction by improving physical quality or enhancing the attributes used (Ali and Amin, 2013). Physical quality can be effectively utilized by the company to reinforce the company's brand image and directly improve customer satisfaction (Ryu et al, 2012: 95). Previous research such as Ali and Muqadas (2015), Ali et al (2016), Kumalaningrum et al (2016), Molinillo et al (2015), Prabowo (2017), Rizqy et al (2015), Sardar and Shahrarki (2015), Sugandhy et al (2016), Susanty and Kenny (2015) and Yuriansyah (2013) showed that physical quality is an antecedent of customer satisfaction and that the two constructs must positively associate each other. Thus formed the first hypothesis in this study is:

$\mathrm{H}_{1}$ : There is a positive relationship between physical quality and customer satisfaction.

The staff or employees of an organization are important factors in shaping customer perceptions and satisfaction, as they are the people ultimately responsible for providing quality services that meet customer expectations (Susanty \& Kenny, 2015). The behavior of staff is an image projected by the competence, courtesy, friendliness and responsiveness of the staff (Nam et al, 2011). The behavior of staff can affect consumers' perceptions of service quality, because success and failure of service delivery are based on attitudes and behaviors of staff who make contact with customers (Alhelalat et al, 2017). Staff who deal directly with customers can influence customer perceptions of the services of a brand (Turkey \& Sengul, 2014). Moreover, staff behavior affect the quality of the relationships that are established between customers and companies (Turkey \& Sengul, 2014). Previous research shows that the explicit service attributes and the attention and courtesy of staff also positively affect the customer satisfaction of Ali and Muqadas (2015), Ali et al (2016), Budiman et al (2013), Kumalaningrum et al (2016), Molinillo et al (2015), Prabowo (2017), Sardar and Shahrarki (2015), Sugandhy et al (2016), Susanty and Kenny (2015) and Yuriansyah (2013). Hence the second hypothesis of this study is established:

$\mathrm{H}_{2}$ : There is a positive relationship between staff behavior and customer satisfaction.

Congruence refers when people see that their self-concept is in accordance with the image of the object. Ideal self-congruence refers to whether there is a gap between what customers perceive about the brand and what customers actually expect from the brand (Shahroodi et al, 2015: 3). In other words, the ideal fit of one's self can affect their satisfaction or affect customer satisfaction. Therefore, ideal self-congruence can lead to 
satisfaction because positive conformity between self-image and brand image can lead to a positive and high level of satisfaction. Previous research has shown that ideal selfcongruence can be used to predict customer satisfaction of Ali and Muqadas (2015), Berezan et al (2017), Gunawan et al (2013), Jorfi and Gayem (2016), Kim et al (2016), Molinillo et al (2015), Moradi et al (2014), Nasri (2015), Rabie et al (2015), Sardar and Shahrarki (2015) and Susanty and Kenny (2015). Thus, it is likely that customers will show a positive response to the coffee shop when they feel that the coffee shop atmosphere (another image of the customer) matches their self-image. Based on the above statement, the third hypothesis in this study is as follows:

$\mathrm{H}_{3}$ : There is a positive relationship between ideal self-congruence and customer satisfaction.

Brand identity is where the company creates a brand meaning in the minds of customers (Shahroodi et al, 2015: 3). To be effective, brand identity needs to resonate with consumers, differentiate brands with competitors and represent what the company will do over time. Brand identification also affects the success of a company in terms of getting satisfied customers (Ali \& Muqadas, 2015: 849). Previous research shows that brand identification significantly positive effect on customer satisfaction. In the specific, customers with a high level of brand identification will feel proud of being brand owners or satisfied when consuming certain brand products (Susanty \& Kenny, 2015). The positive influence of brand identification on customer satisfaction is supported by previous research by Ali and Muqadas (2015), Jorfi and Gayem (2016), Kim et al (2017), Kumar (2014), Molinillo et al (2016), Moradi et al (2014), Popp and Woratschek (2017), Rabie et al (2015), Sardar and Sharaki (2015), Shirazil et al (2013) and Susanty and Kenny (2015). Based on the above statement, the fourth hypothesis in this study is:

$\mathrm{H}_{4}$ : There is a positive relationship between brand identification and customer satisfaction.

The lifestyle-congruence expresses the suitability of the customer's lifestyle and relates to the desired customer's desired fit (Garg et al, 2017). Furthermore, Garg et al. (2017) pointed-out that lifestyle-congruence is one component to improve customer satisfaction. Brands are built and reinforced by describing the experience and lifestyle desired when using the product (Cassewell \& Maxwell, 2005 cited by Susanty \& Kenny, 2015). The higher the level of brand image in accordance with the lifestyle of consumers, the greater the consumer satisfaction with the brand experience. Previous studies conducted by Ali and Muqadas (2015), Aluregowda (2013), Artanta and Hatane (2016), Jorfi and Gayem (2016), Molinillo et al (2016), Moradi et al (2014), Rabie et al (2015), Sardar and Sharaki (2015), Shahroodi et al (2015) and Susanty and Kenny (2015) show a significant positive relationship between lifestyle-congruence and customer satisfaction. Then, the fifth hypothesis of this study proposes that:

$\mathrm{H}_{5}$ : There is a positive relationship between lifestyle-congruence and customer satisfaction.

Loyalty is a strong attachment to the brand as evidenced by the company's inherent behavior, recommending its product, purchasing additional products or services from it, and so on (Susanty \& Kenny, 2015). According Shahroodi et al (2015) the increasing of customer satisfaction will affect the increasing in brand loyalty. It can be stated that satisfaction is a key indicator of winning customer loyalty to certain brands over the long 
term (Susanty \& Kenny, 2015). Hypothesis test results that have been done show that customer satisfaction significantly positive effect on brand loyalty (Shahroodi et al, 2015). Previous study showed that satisfaction is the main antecedent of brand loyalty by Ali and Muqadas (2015), Jorfi and Gayem (2016), Kumalaningrum et al (2016), Kumar (2014), Molinillo et al (2016), Moradi et al (2014), Nam et al (2011), Rabie et al (2015), Sardar and Sharaki (2015) and Zhang (2015). Therefore the sixth hypothesis in this study is:

$\mathrm{H}_{6}$ : There is a positive relationship between customer satisfaction and brand loyalty.

Based on explanation above, the research model can be offered as in Figure 1.

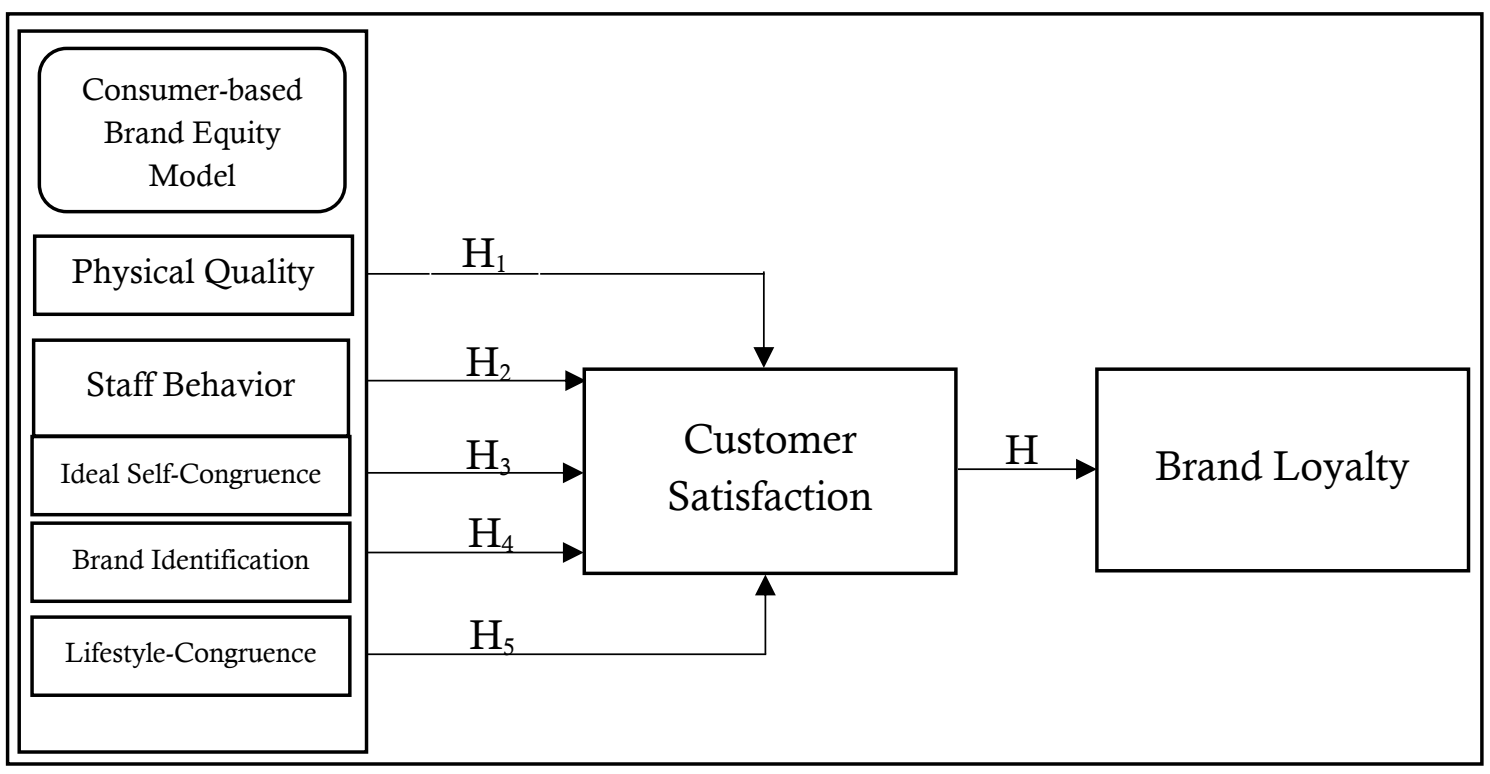

Figure 1. Research Model (Source: Susanty and Kenny, 2015)

\section{METHOD}

This research applied a quantitative paradigm. This paradigm is appropriate for use in this study because this study aims to examine the relationship between variables by analyzing data with statistical techniques (Creswell, 2013). Quantitative research uses statistical methods to clarify hypotheses and find out the relationships between variables (Malhotra, 2015).

The object of research is anything in the form of what is determined by the researcher to be studied in order to obtain information about it and can be drawn conclusion (Sudaryono, 2017: 151). Object used in this research is coffee shop. There are two reasons why researchers choose coffee shops as research objects. First, the researchers see that students cannot be separated from the gathering together with their peers. Furthermore, where to gather it most students choose coffee shops as an option because it provides the facilities they need such as Wi-Fi, drinks and food. Secondly, today many coffee shops emerge from various brands by presenting what the needs of its customers; it is interesting for researchers to know the factors that can make customer satisfaction and their loyalty to the coffee shop. In this study there are two brands of coffee shops that want to be examined for comparisons between a single coffee shop brand with a second coffee shop brand, which 
aims to investigate the relationship between brand equity, customer satisfaction and brand loyalty in coffee shop industry represented by Starbucks and Djournal Coffee.

Researchers applied the Starbucks brand (as a foreign brand) because Starbucks is a famous coffee shop brand that already has many loyal customers. While Djournal Coffee was selected based on a survey that has been given by researchers to 25 students of one private university in Tangerang and 14 students answered that Djournal Coffee is a coffee shop brand that is equivalent to Starbucks representing brands from Indonesia. Starbucks is a global brand, while Djournal Coffee is one of the local coffee shop brands that compete with Starbucks. The reason researchers compare these two brands of coffee shops as objects for research is to see, if consumers are given different brand choices, whether consumers will make choices on global brands compared to brands originating from Indonesia.

Data were collected through personally administered questionnaire (personally administered questionnaire). Three main reasons for using the self-adminstered questionnaires. The first reason, by distributing questionnaires personally can build relationships between researchers and respondents. Secondly, the affordable cost incurred to conduct the distribution of uestionnaires. Finally, the security of the identity and responses of the respondents is high because the answers given are directly keeped by researchers (Sekaran \& Bougie, 2016).

In this study, researchers used individual units of analysis because researchers wanted to know the opinions of each person who likes to sit down while drinking coffee and doing something at Starbucks and Journal Coffee. Individuals who were appointed by the researchers were students of XYZ University in Karawaci. There are three reasons why researchers appoint these individuals. First, because XYZ University students in Karawaci has a middle and upper economic level and this is in accordance with the object of research used, namely Starbucks and Journal Coffee which is a coffee shop for the upper middle class. Secondly, due to time and cost limitations that make researchers unable to conduct research objects and individual selection outside the area of residence of the researcher. And lastly, because XYZ University students can represent the data used because visitors who come to the coffee shop are mostly 18-22 years old and are students.

The variable is an empirical assessment of a concept that is assumed to be a different value (Bernard, 2017). The research variables were measured using indicators based on previous studies (Wang \& Sengupta, 2016; Alnawas \& Altarifi, 2015; Susanty \& Kenny, 2015; Kusuma, 2014; Turkey \& Sengul, 2014: Widjoyo et al., 2013 ). Specifically, physical quality is measured using four indicators : (1) The coffee shop equipment is aesthetically pleasing, (2) This coffee shop offers good Wi-fi connection, (3) The coffee shop is visually appealing, and (4) Coffee shop this gave me an interesting visual space. Another variable, staffs behavior, was measured by the following 4 indicators: (1) This coffee shop staff listened to customer complaints including me, (2) The coffee shop staff helped me in choosing the best menu, (3) The staff of this coffee shop was friendly with customers, and (4) The staff of this coffee shop can not answer questions from customers.

The idel self-congruence is measured by 4 indicators. The four indicators are: (1) I feel similar to the consumers who consume the brand products of this coffee shop, (2) The 
brand image of this coffee shop according to myself, (3) According to others, the brand image of this coffee shop is in accordance with myself, and (4) The brand of this coffee shop reflects my ideal personality. Brand identification variables are also measured using four indicators, namely: (1) My personality is similar to the brand of this coffee shop, (2) If a story in the media criticize this coffee shop, I would feel ashamed, (3) When someone criticizes the coffee shop, it such as personal humiliation, and (4) The brand of this coffee shop has a good reputation.

The lifestyle suitability is measured using the following four indicators: (1) Coffee shops reflect my personal lifestyle, (2) This brand fits my lifestyle, (3) Using this coffee shop product supports my lifestyle, and (4) my lifestyle can change if there is no brand of coffee shop this. Customer satisfaction is measured by the following 4 indicators: (1) Overall, the service provided by the coffee shop employees is satisfactory, (2) Overall, the drinks served by this coffee shop are satisfactory, (3) Overall, the food served by this coffee shop satisfactory, and (4) Overall, the room layout presented by this coffee shop is satisfactory. Loyalty is measured using 4 indicators, namely: (1) I will not use another brand if there is a price increase on this brand, (2) After consuming this coffee shop for the first time I will stick with this coffee shop, (3) I never switch to another coffee shop if you have problems with this coffee shop, and (4) I consume this coffee product repeatedly because my experience in consuming coffee shop products is fun.

This research uses purposive sampling method. Thus, the selected sample must have certain criteria to be respondent (Sekaran \& Bougie, 2016). The criteria are the respondents have made purchases at Starbucks and Djournal Coffee. The number of samples in this study includes 260 respondents (130 samples of Starbucks and 130 Djournal Coffee).

Goodness measures through reliability and validity test data (Sirakaya-Turk et al, 2017). Reliability refers to whether researchers get the same answer by using an instrument to measure something more than once (Bernard, 2017). While validity refers to whether the researcher has measured the concept correctly (Sekaran \& Bougie, 2016). This research uses reliability testing by using internal consistency Cronbach alpha with minimum threshold that is 0,6. (Sekaran \& Bougie, 2016; Hair et al., 2010). The treshold of corrected item-total correlation applied in this research is 0.3 (Hair et al., 2015).

Validity test is done by applying the construct validity. This type of validity represents the degree to which a measurement assesses the theoretical concepts designed to be judged (Shaughnessy et al., 2012). Furthermore, construct validity is achieved if it meets the validity of convergence and discriminant validity. In this study using exploratory factor analysis (EFA) to test the validity of convergent measurement scale (Iyamu, 2015). In the specific, an indicator is said to meet the validity of convergence if it has a loading factor value of $\geq 0.7$ and discriminant validity will be achieved if the correlation limit is $<0.7$ (Ghozali \& Latan, 2015). Thus, this research uses a load factor with the threshold of 0.7 for the validity of convergent and uses the correlation with the threshold of 0.7 to achieve the discriminant validity test can be achieved.

Structural Equation Model (SEM) is a method of statistical analysis to describe the relationship model among variables (Hoyle, 2014). There are three main reasons underlying 
the use of SEM. First, SEM has the ability to estimate the relationship between variables that are dual relations (Sudaryono, 2017). This relationship is formed in a structural model (the relationship between independent and dependent constructs). Secondly, SEM has the ability to describe patterns of relationship between latent constructs and manifest variables (Sudaryono, 2017). Finally, this study has intervening variables, so that the existing research intervening variables can use SEM testing (Schumacker \& Lomax, 2015).

Table 2. Indicator loadings values

\begin{tabular}{|c|c|c|}
\hline & $\begin{array}{l}\text { Indicator Loadings } \\
\text { (Djournal Coffee) }\end{array}$ & $\begin{array}{c}\text { Indicator Loadings } \\
\text { (Starbucks) }\end{array}$ \\
\hline $\mathrm{PQ} 1 \leftarrow \mathrm{PQ}$ & 0,798 & 0,873 \\
\hline $\mathrm{PQ} 3 \leftarrow \mathrm{PQ}$ & 0,868 & 0,767 \\
\hline $\mathrm{PQ}_{4} \leftarrow \mathrm{PQ}$ & 0,823 & 0,738 \\
\hline $\mathrm{SB} 1 \leftarrow \mathrm{SB}$ & 0,865 & 0,817 \\
\hline $\mathrm{SB} 2 \leftarrow \mathrm{SB}$ & 0,809 & 0,789 \\
\hline $\mathrm{SB} 3 \leftarrow \mathrm{SB}$ & 0,827 & 0,782 \\
\hline ISC $1 \leftarrow$ ISC & 0,860 & 0,847 \\
\hline ISC $2 \leftarrow$ ISC & 0,889 & 0,887 \\
\hline $\mathrm{ISC} 3 \leftarrow \mathrm{ISC}$ & 0,892 & 0,864 \\
\hline $\mathrm{BI} 1 \leftarrow \mathrm{BI}$ & 0,958 & 0,936 \\
\hline $\mathrm{BI} 2 \leftarrow \mathrm{BI}$ & 0,587 & 0,733 \\
\hline $\mathrm{BI} 3 \leftarrow \mathrm{BI}$ & 0,644 & 0,783 \\
\hline $\mathrm{LC} 1 \leftarrow \mathrm{LC}$ & 0,935 & 0,920 \\
\hline $\mathrm{LC} 2 \leftarrow \mathrm{LC}$ & 0,914 & 0,908 \\
\hline $\mathrm{LC} 3 \leftarrow \mathrm{LC}$ & 0,823 & 0,922 \\
\hline $\mathrm{CS} 1 \leftarrow \mathrm{CS}$ & 0,881 & 0,791 \\
\hline $\mathrm{CS} 2 \leftarrow \mathrm{CS}$ & 0,842 & 0,771 \\
\hline $\mathrm{CS} 3 \leftarrow \mathrm{CS}$ & 0,832 & 0,836 \\
\hline $\mathrm{CS} 4 \leftarrow \mathrm{CS}$ & 0,838 & 0,628 \\
\hline $\mathrm{BL} 1 \leftarrow \mathrm{BL}$ & 0,877 & 0,912 \\
\hline $\mathrm{BL} 2 \leftarrow \mathrm{BL}$ & 0,859 & 0,927 \\
\hline
\end{tabular}

Legend: PQ : Physical Quality, SB : Staff Behavior, ISC : Ideal Self-Congruence, BI : Brand Identification, LC : Lifestyle-congruence, CS : Customer Satisfaction, BL : Brand Loyalty

\section{FINDING AND DISCUSSION}

Two hundred and sixty questionnaires were distributed to respondents in both Starbucks and Djournal Coffee shops. Out of 260 questionnaires, 249 were returned from those coffee shops. Specifically, there were 123 questionnaires returned by respondents from Djournal Coffee and 126 from Starbucks. The number of questionnaires obtained represent response rate of $95.76 \%$. The high rate of return is achieved due to the method of distributing the questionnaire personally. The advantages of using this method of dissemination are able to build good relationships with respondents and motivate respondents and then clarify the 
doubts experienced by respondents and the last response-rate given respondents reached up to $100 \%$ (Sekaran and Bougie, 2016). Of the 249 returned questionnaires, there were 9 questionnaires that could not be further processed because they were incomplete in the questionnaire filling. Thus, there are 240 questionnaires that can be further processed.

Profile of respondents can be submitted as follows. The majority of respondents are either respondent whose data are taken from foreign or local brand coffee shops aged 20 to 22 years. More than half of the respondents in the local coffee shop are men while more than half of the respondents in overseas coffee shops are female. However, the intensity of both respondents' coffee shop with foreign and local brands is up to 3 times per month.

The measurement model was performed before the structural model. Specifically, the measurement model aims to test composite reliability, absolute standardized loading. The analysis shows that the composite reliability value ranges from 0.784 to 0.940 . The average variance extracted (AVE) is in the range of 0.559 to 0.845 . Table 2 shows the value of indicator loadings.

Tables $3 \mathrm{a}$ and $3 \mathrm{~b}$ show the results of Fornell-Larcker discriminant validity test in which the AVE root for each construct is larger than the correlation between constructs and other constructs it can be said to qualify the discriminant validity of Fornell-Larcker. The construct validity in this research has been achieved because it meets the predefined requirements.

Table 3a. The results of discriminant validity (Fornell-Larcker) for Starbucks

\begin{tabular}{ccccccccc}
\hline Variabel & AVE & BI & PQ & LC & ISC & CS & BL & SB \\
\hline BI & 0,676 & $\mathbf{0 , 8 2 2}$ & & & & & & \\
PQ & 0,632 & 0,168 & $\mathbf{0 , 7 9 5}$ & & & & & \\
LC & 0,840 & 0,714 & 0,192 & $\mathbf{0 , 9 1 6}$ & & & & \\
ISC & 0,750 & 0,728 & 0,262 & 0,633 & $\mathbf{0 , 8 6 6}$ & & & \\
CS & 0,578 & 0,346 & 0,372 & 0,457 & 0,409 & $\mathbf{0 , 7 6 0}$ & & \\
BL & 0,845 & 0,466 & 0,271 & 0,537 & 0,476 & 0,511 & $\mathbf{0 , 9 2 0}$ & \\
SB & 0,634 & 0,291 & 0,347 & 0,304 & 0,296 & 0,378 & 0,167 & $\mathbf{0 , 7 9 6}$ \\
\hline
\end{tabular}

Table 3b. The results of discriminant validity (Fornell-Larcker) for Djournal Coffee

\begin{tabular}{ccccccccc}
\hline Variabel & AVE & BI & PQ & LC & ISC & CS & BL & SB \\
\hline BI & 0,559 & $\mathbf{0 , 7 4 8}$ & & & & & & \\
PQ & 0,689 & 0,366 & $\mathbf{0 , 8 3 0}$ & & & & & \\
LC & 0,795 & 0,634 & 0,385 & $\mathbf{0 , 8 9 2}$ & & & & \\
ISC & 0,776 & 0,723 & 0,379 & 0,744 & $\mathbf{0 , 8 8 1}$ & & & \\
CS & 0,720 & 0,340 & 0,606 & 0,489 & 0,425 & $\mathbf{0 , 8 4 9}$ & & \\
BL & 0,754 & 0,478 & 0,247 & 0,411 & 0,621 & 0,298 & $\mathbf{0 , 8 6 8}$ & \\
SB & 0,696 & 0,302 & 0,409 & 0,347 & 0,342 & 0,600 & 0,311 & $\mathbf{0 , 8 3 4}$ \\
\hline
\end{tabular}

To test research hypotheses, structural model was examined by using the software PLS. The results of all research hypotheses for both foreign and local are presented in Table $4 \mathrm{a}$ and $4 \mathrm{~b}$.

Hypothesis 1 states that there is a significant relationship between physical quality and customer satisfaction in both coffee shops. This hypothesis is supported in accordance 
with previous research where the physical quality is related to customer satisfaction of Ali and Muqadas (2015), Ali et al (2016), Kumalaningrum et al (2016), Molinillo et al (2015), Prabowo (2017), Rizqy et al (2015), Sardar and Shahrarki (2015), Sugandhy et al (2016), Susanty and Kenny (2015) and Yuriansyah (2013) who stated that physical quality is the antecedent of consumer satisfaction and that the two constructs must positively associate each other one another.

Tabel 4a. The results of structural model (Starbuck)

\begin{tabular}{cccccc}
\hline Hyphoteses & $\begin{array}{c}\text { Variabel } \\
\text { relationship }\end{array}$ & $\begin{array}{c}\text { Coefficient } \\
\text { path valu }\end{array}$ & CR & P-value & Conclusion \\
\hline H1 & PQ $\rightarrow$ CS & 0,220 & 2,756 & 0,003 & Supported \\
H2 & SB $\rightarrow$ CS & 0,183 & 2,149 & 0,016 & Supported \\
H3 & ISC $\rightarrow$ CS & 0,157 & 0,117 & 0,090 & Not Supported \\
H4 & BI $\rightarrow$ CS & $-0,089$ & 0,708 & 0,240 & Not Supported \\
H5 & LC $\rightarrow$ CS & 0,323 & 2,617 & 0.005 & Supported \\
H6 & CS $\rightarrow$ BL & 0,511 & 7,382 & 0,000 & Supported \\
\hline
\end{tabular}

Table $4 b$. The results of structural model (Djournal Coffee)

\begin{tabular}{cccccc}
\hline Hypotheses & $\begin{array}{c}\text { Variable } \\
\text { relationship }\end{array}$ & $\begin{array}{c}\text { Coefficient path } \\
\text { value }\end{array}$ & $\begin{array}{c}\text { Critical } \\
\text { Ratio }\end{array}$ & P-value & Conclusion \\
\hline $\mathrm{H}_{1}$ & $\mathrm{PQ} \rightarrow \mathrm{CS}$ & 0,377 & 4,978 & 0,000 & Supported \\
$\mathrm{H}_{2}$ & $\mathrm{SB} \rightarrow \mathrm{CS}$ & 0,377 & 5,081 & 0,000 & Supported \\
$\mathrm{H}_{3}$ & $\mathrm{ISC} \rightarrow \mathrm{CS}$ & 0,043 & 0,355 & 0,361 & Not Supported \\
$\mathrm{H}_{4}$ & $\mathrm{BI} \rightarrow \mathrm{CS}$ & $-0,095$ & 0,822 & 0,206 & Not Supported \\
$\mathrm{H}_{5}$ & $\mathrm{LC} \rightarrow \mathrm{CS}$ & 0,241 & 2,426 & 0.008 & Supported \\
$\mathrm{H}_{6}$ & $\mathrm{CS} \rightarrow \mathrm{BL}$ & 0,298 & 2,690 & 0,004 & Supported \\
\hline
\end{tabular}

Hypothesis 2 shows there is a significant relationship between staff behavior and customer satisfaction. These results show that there is an influence between the behavior of staff and customer satisfaction, if the staff behavior in the coffee shop is good then the customer will be satisfied. This hypothesis is supported by previous research by Ali and Muqadas (2015), Ali et al (2016), Budiman et al (2013), Kumalaningrum et al (2016), Molinillo et al (2015), Prabowo (2017), Sardar and Shahrarki (2015), Sugandhy et al (2016), Susanty and Kenny (2015) and Yuriansyah (2013).

Hypothesis 3 shows the insignificant relationship between ideal self-congruence and customer satisfaction. Thus the third hypothesis in this study is not supported, because the ideal self-congruence is not related to customer satisfaction. The insignificant result of this research can be related to the profile of respondents who are mostly aged between 20-22 years. According Strom and Strom (2009) adolescence is seen at the age between 14 and 24 years. Adolescence is an inconsistent period and tends to follow friends or parents (Darlon, 2007). According to Kanserina (2015) teen market share is the main target for producers. Furthermore, students are teenagers with a tendency to have a high consumption, because students consume a good or service not because they need or to fit themselves but the impulsive aspect that makes students behave consumptive (Kanserina, 2015: 4). This makes their ideal fit conformity not affecting satisfaction because the student consumes the related 
coffee shop product because of their impulsive factor. This hypothesis is also not supported from previous research that is the work of Widjiono and Japarianto (2015), and Jamal (2004). Therefore this third hypothesis is not supported.

Hypothesis 4 shows the insignificant relationship between brand identification and customer satisfaction. Furthermore, customers from both brands of coffee shops are not too enthusiastic to identify themselves with this brand. From the results of statistical data can be said brand identification does not affect customer satisfaction. Customers pay more attention to other factors such as physical quality, staff behavior and lifestyle conformity. In this study the respondents were dominated by adolescents, why this hypothesis is not supported because adolescence is a time when everyone is trying to find his own identity (Wise, 2004). Furthermore, as stated the first indicator of brand identification "My personality is similar to this coffee shop", customers are not too enthusiastic to identify and associate themselves with this brand, so the sense of ownership of the customers against the brand's coffee shop is not an important factor for satisfaction. Because the majority of respondents to this study are teenagers, so they have not been able to identify them. This hypothesis is also not supported from previous research that is the work of Susanty and Kenny (2015).

Hypothesis 5 shows there is a significant relationship between lifestyle-congruence and customer satisfaction. These results suggest there is an influence between lifestylecongruence and consumer satisfaction. The existence of a significant relationship between lifestyle-congruence and customer satisfaction is supported similarly to previous research of Ali and Muqadas (2015), Aluregowda (2013), Artanta and Hatane (2016), Jorfi and Gayem (2016), Molinillo et al (2016), Moradi et al (2014), Rabie et al (2015), Sardar and Sharaki (2015), Sharodi et al (2015) and Susanty and Kenny (2015).

Hypothesis 6 shows there is a significant relationship between customer satisfaction and brand loyalty. These results indicate there is an influence between the suitability of lifestyle and consumer satisfaction, the more satisfied consumers with the coffee shop then the consumer can be a loyal consumer. This hypothesis is supported similarly to the previous research of Ali and Muqadas (2015), Jorfi and Gayem (2016), Kumalaningrum et al (2016), Kumar (2014), Molinillo et al (2016), Moradi et al (2014), Nam et al (2011), Rabie et al (2015), Sardar and Sharaki (2015), Susanty and Kenny (2015) and Zhang (2015).

From the results obtained in this study there are four of the six hypotheses supported and there are two unsupported hypotheses. Associated with the results of the hypothesis there are some things that need to be considered by the coffee shop Djournal Coffee and Starbucks Coffee. From the first hypothesis can be seen the physical quality affects customer satisfaction. It can be stated that for both two coffee shops (i.e., Djournal Coffee and Starbucks), the physical environment of their coffee shop is an important element that affect customer satisfaction. This physical environment includes decoration, table equipment, chairs, sofa to coffee equipment, and others. Furthermore, creative unique designs that can spoil the eyes of their customers so that customers feel comfortable and want to linger in the coffee shop. 
The behavior of their staff needs to be taken into account in serving the customers of the coffee shop, because their attitude in dealing with customers affects customer satisfaction. Djournal Coffee can conduct training on their new employees, and orientate new employees. Orientation is useful to increase employee knowledge about the coffee shop industry, so as to understand the whole about the coffee shop. Providing commissions, bonuses, recreation for fellow employees of the coffee shop also improves employee work motivation, so they work harder so that the services provided according to customer expectations of the coffee shop and get customer satisfaction. It should also be noted that customers can provide direct criticism and advice to the coffee shop, so that the managers of the two coffeehouses know the natural problems or shortcomings.

In the third hypothesis result stated that the ideal self-congruence does not affect customer satisfaction. Specifically, for customers in Djournal Coffee and Starbucks Coffee, they do not paying much attention to their own ideal self-congruence in the coffee shop; but, they pay more attention to the quality provided by the coffee shop. In the fourth hypothesis also states that brand identification does not affect customer satisfaction. This statement should be noted by Djournal Coffee and Starbucks Coffee in brand identification and instill a good mind in their consumers that the products consumed by them are quality products

It can be said that the current lifestyle, especially the age of 18 to 27 years is identical with coffee, and can be seen from the profile of private respondents visiting Djournal and Starbucks coffee shop three or more times a month. So it has become their habit to visit the coffee shop. Moreover, the location of Starbucks Coffee and Djournal Coffee strategically adjacent to the university, so that the university students can reach it more easily, making the habits of university students to visit the coffee shop. The second manager of the coffee shop can provide discounts to nearby university students, to increase their motivation in buying Djournal Coffee or Starbucks Coffee products.

\section{CONCLUSION}

The results showed that there are four of the six hypotheses supported and there are two unsupported hypotheses. This research is not separated from the limitations of the study as follows. The first limitation of the research relates with 2 coffee shops in a specific location (i.e., Starbucks coffee shop and Djournal Coffee in Karawaci area, Indonesia) applied as the research object. Therefore, this study can not be used as representative for coffee shops other than objects of this research.

The second limitation is relating with the use of non probability sampling. By using this sampling method the whole of the population did not get the same probability to be the respondent in this study. Thus, the results of this study can not be generalized into other objects, context, and others.

Based on the limitations of the study and the results of this study, it can be offered some suggestions for further research. The first suggestion is based on the research object. In other words, future research may apply different brand names of coffee shops. It aims to produce new knowledge in science. The second suggestion is that further research can select 
different analytical units. Analytical units that can be used such as office employees, residential neighborhood communities or school students who like to drink coffee. This is because by using different analytical units are expected to generalize the research results.

The third suggestion is to use different variables when using the research object is a coffee shop. These variables can come from the researchers themselves by looking at the phenomena that occur around the coffee shop in order to form a new model of consumer loyalty in coffee shops. And the last suggestion is to conduct future research outside the city. In the specific, many studies about coffee shops in urban areas while many coffee shops also locate in suburb areas. The use of coffee shops located in the suburbs will offer new findings about the phenomenon that occurred there.

\section{REFERENCES}

Albert, N. \& Merunka, D. (2013). The Role of Brand Love in Consumer-Brand Relationships. Journal of Consumer Marketing, 30(3), 256-288.

Alhelalat, J. A., Habiballah, M. A. \& Twaissi, N. N. (2017). The impact of personal and functional aspects of restaurant employee service behaviour on customer satisfaction. Jordan: International Journal of Hospitality Management, 66, 46-53. doi:10.1016/j.ijhm.2017.07.001.

Ali, F. \& Muqadas, S. (2015). The Impact of Brand Equity on Brand Loyalty: The Mediating Role of Customer Satisfaction. Pak J Commer Soc Sci Pakistan Journal of Commerce and Social Sciences, 9(3), 890-915.

Ali, F., Omar, R. \& Amin, M. (2013). An Examination of the Relationship between Physical Environment, Perceived Value, Image and Behavioural Intentions: A SEM Approach towards Malaysian Resort Hotels. Journal of Hotel and Tourism Management, 27(2), 9-26.

Ali, F., Kim, W. G., Li, J. \& Jeon, H. M. (2016). Make it Delightful: Customer's Experience, Satisfaction and Loyalty in Malaysian theme parks. Journal of Destination Marketing Management, 1-11. doi:10.1016/j.jdmm.2016.05.003.

Amelia, P., Budisantoso, I. \& Wirjodirdjo. (2012). Dinamika Pengembangan Subsektor Industri Makanan Dan Minuman Di Jawa Timur: Pengaruh Investasi Terhadap Penyerapan Jumlah Tenaga Kerja. Jurnal Teknik POMITS, 1(1), 1-6.

Anggraeni, R. D. (2014). Loyalitas Konsumen Kedai Kopi Di Surabaya (Studi Deskriptif Loyalitas Konsumen Coffee Toffee di Surabaya). Jurnal Commonline Departemen Komunikasi, 3(210), 259-268.

Arokiasamy \& Abdullah, R. A. (2013). Service Quality and Customer Satisfaction in the Cellular Tellecomunication Service Provider in Malaysia. Researchers World: Journal of Arts, Science \& Commerce, 4(2), 1-9.

Artanta, Y. P. \& Hatane, S. E. (2016). Analisa Pengaruh Brand Equity Terhadap Kinerja Keuangan Melalui Customer Satisfaction sebagai Variabel Intervening pada Perusahaan Perbankan di Surabaya. Journal of Business Accounting review, 4(1), 49-60.

Asamoah, E. S. (2014). Customer based brand equity (CBBE) and the competitive performance of SMEs in Ghana. Journal of Small Business and Enterprise Development, 21(1), 117-131. doi:10.1108/JSBED-10-2013-0154. 
Baker, M. J. (2014). Marketing Strategy and Management ( $5^{\text {th }}$ ed.). New York: Palgrave.

Balakrishnan, B., Dahnil, M. I. \& Yi, W. J. (2014). The Impact of Social Media Marketing Medium Toward Purchase Intention and Brand Loyalty Among Generation Y. Procedia-Social and Behavioral Science, 148, 177-185. doi:10.1016/j.sbspro.2014.07.032.

Barus, H. C. (2015). Pengaruh Ekuitas Merek (Brand Equity) Terhadap Keputusan Pembelian Smartphone Blackberry. (Studi pada Mahasiswa Program S1 Jurusan Administrasi Bisnis Fakultas Ilmu Sosial dan Ilmu Politik). Jurnal Ilmu Administrasi Bisnis, 4(1), 1-7.

Berezan, O., Krishen, A. S., Tanford, S. \& Raab, C. (2017). Style Before Substance? Building Loyalty through Marketing Communication Congruity. European Journal of Marketing, 51(7/8), 1-39.

Budiman, D., Naibaho, H. \& Amelia. (2013). Pengaruh Kualitas Layanan, Kualitas Produk, Kepuasan Pelanggan Terhadap Kesetiaan Merek Starbucks di Surabaya. Jurnal Gema Aktualitas, 2(1), 81-88.

Creswell, J. W. (2013). Research Design: Qualitative, Quantitative and Mixed Methods Approaches $\left(4^{\text {th }}\right.$ ed.). SAGE Publication.

Darlon, E. B. (2007). Adolescent Behavior Research Advance. New York: Nova Science Publishers, Inc.

Ekinci, Y., Turk, E. S. \& Preciado, S. (2013). Symbolic Consumption of Tourism Destination Brands. Elsevier Inc: Journal of Business Research, 66, 711-718.

Ermawati, P. W., Sudiro, A. \& Khusniyah, N. (2016). Pengaruh Kesadaran Merek dan Asosiasi Merek terhadap Ekuitas Merek pada Pelanggan Hypermarket di Kota Malang. Jurnal Aplikasi Manajemen (JAM), 14(2), 373-386.

Garg, R., Chhikara, R., Panda, T. K. \& Kataria, A. (2017). Driving Customer Appeal through the used of Emotional Branding. IGI Global Publisher.

Ghozali, Prof. Dr. H. I. \& Latan, H. (2015). Partial Least Square. Concept, Teknik dan Aplikasi menggunakan program Smart PLS 3.0 (2 $2^{\text {nd }}$ ed.). Universitas Dipenogoro, Semarang.

Hadiwidjaja, R. S. \& Dharmayanti, D. (2015). Analisa Hubungan Experiental Marketing, Kepuasan Pelanggan, Loyalitas Pelanggan Starbucks Coffee di Surabaya Town Square. Jurnal Manajemen Pemasaran, 2(2), 1-11.

Hair, J. F. Jr., Celsi, M., Money, A., Samouel, P. \& Page, M. (2015). The Essentials of Business Research Methods ( $3^{\text {rd }}$ illustrated ed.). Routledge.

Han, S. H., N, B. \& Lee, T. J. (2015). Consumer-based chain restaurant brand equity, brand reputation, and brand trust. International Journal of Hospitality Management, 50, 84-93. doi:10.1016/j.ijhm.2015.06.010.

Johansson, J. K. \& Carlson, K. A. (2014). Contemporary Brand Management (1 $1^{\text {st }}$ ed.). SAGE Publications, inc.

Jorfi, S. \& Gayem, A. (2016). Brand Equity, Brand Loyalty and Customer Satisfaction (Case study consumer goods of brand Samsung in shops of Khuzestan). International Journal of Humanities and Cultural Studies, 1981-1996. 
Kanserina, D. (2015). Pengaruh Literasi Ekonomi dan Gaya Hidup Terhadap Perilaku Konsumtif Mahasiswa Jurusan Pendidikan Ekonomi Undiksha 2015. Jurnal Pendidikan Ekonomi Undiksha, 5(1), 1-11.

Kim, S. H., Kim, M. \& Holland, S. (2016). How Customer Personality Traits Influence Brand Loyalty in The Coffee Shop Industry: The Moderating Role of Business Types. International Journal of Hospitality \& Tourism Administration, 1-25.

Kuenzel, S. \& Halliday, S. (2008). Brand identification: A Theory-based construct for conceptualizing links between corporate branding, identity and communications. In: Melewar, T.C.

Kumalaningrum, F., Widajanti, E. \& Sutarno. (2016). Analisis Pengaruh Kualitas Pelayanan Terhadap Loyalitas Konsumen dengan Kepuasan Konsumen Sebagai Variabel Moderasi (Studi pada Konsumen CS Kopi Tubruk Surakarta). Jurnal Ekonomi dan Kewirausahaan, 16(2), 226-233.

Kotler, P. \& Armstrong, G. (2014). Principles of Marketing (15 $5^{\text {th }}$ ed). New Jersey: Pearson Education.

Larasati, V. \& Suryaputra, R. (2013). Analisis Faktor-faktor yang Mempengaruhi Loyalitas Pelanggan Coffee Toffee Jatim Expo di Surabaya. Jurnal Gema Aktualita, 2(2), 7-17.

Lee, S. \& Jeong, M. (2012). Effects of e-Servicescape on Consumers' Flow Experiences. Journal of Hospitality and Tourism Technology, 3(1), 47-59. doi:10.1108/17579881211206534.

Lovelock, C. \& Patterson, P. (2015). Service Marketing. Australia: Pearson Australia.

Lu, J. \& Xu, Y. (2015). Chinese Young Consumers' Brand Loyalty toward Sportswear Products: A Perspective of Self-Congruity. Journal of Product \& Brand Management, 24(4), 365-376. doi: 10.1108/JPBM-05-2014-0593.

Mahmud, K. \& Gope, K. (2012). Factors Influencing the Extent of Brand Loyalty of Toilet Soap Users in Bangladesh: A Case Study on Dhaka City. Global Journals Inc, 12(15), 25-33.

Molinillo, S., Ekinci, Y. \& Japutra, A. (2015). A Cross Validation of Consumer Based Brand Equity (CBBE) with Private Labels in Spain. Springer International Publishing, 69(9), 113-132. doi:10.1007/978-3-319-39946-1.

Moradi, M., Asil, S. M. N. P. \& Khanmohammadi, Z. (2014). An Investigation to the Effect of Brand Equity on Brand Loyalty Considering Customer Satisfaction. Journal of Apllied Environmental and Biological Sciences, 4(4), 231-235.

Nam, J., Ekinci, Y. \& Whyatt, G. (2011). Brand Equity, Brand Loyalty and Customer Satisfaction. Annals of Tourism Research, 38(3), 1009-1030. doi:10.1016/j.annals.2011.01.015.

Nasri, I. (2015). Pengaruh Dimensi Ekuitas Merek Terhadap Loyalitas Merek dengan Medias Kepuasan Konsumen The Harvest Restoran di Surabaya. Jurnal STIE Perbanas Surabaya, 1-19.

Prabowo, R. S. (2017). Pengaruh Service Quality Terhadap Customer Satisfaction English First Surabaya Town Square. AGORA Journal, 5(3), 1-10. 
Rabie, M., Ooshaksaraie, M. \& Chirani, E. (2015). The Relationship among Customer Based Brand Equity, Satisfaction and Loyalty in Maskan Bank of Iran. International Journal of Scientific Management and Development, 3(3), 923-929.

Ringim, K. J., Razalli, M. R. \& Hasnan, N. (2012). A Framework of Business Process Reengineering Factors and Organizational Performance of Nigerian Banks. Canadian Center of Science and Education, 8(4), 203-216.

Rizqy, R. R. R., Warso, M. M. \& Fathoni, A. (2016). Pengaruh Kualitas Pelayanan Terhadap Kepuasan Konsumen (Studi Kasus pada Konsumen PT. Graha Service Indonesia Cabang Semarang). Journal of Management, 2(2), 1-40.

Ryu, K., Lee, H. R. \& Kim, W. G. (2012). The Influence of the Quality of the Physical Environment, Food, and Service on Restaurant Image, Customer Perceived Value, Customer Satisfaction, and Behavioral Intentions. International Journal of Contemporary Hospitality Management, 24(2), 200-223. doi:10.1108/09596111211206141.

Samadi, M. \& Irandoost, M. (2016). Study the Relationship Between Self-Congruity and Functional Congruity on Brand Loyalty (Case Study of Customers of Sanandaj City's Restaurants). O Medwell Journals, 10(5), 6693-6700.

Sardar, S. \& Shahraki, M. (2015). Checking the Level of Brand Equity's Impact on The Customer Satisfaction and Loyalty in The Iran Insurance Company. International Review of Management and Business Research, 4(3), 669-67.

Sari, R. A. I., Fauzi, A. Dh. \& Fanani, D. (2015). Pengaruh Ekuitas Merek Terhadap Keputusan Pembelian (Survei pada Warga Temenggungan Sebagai Pelanggan Indomie RT 10 RW 01 Kelurahan Sukoharjo Kecamatan Klojen Kota Malang). Jurnal Administrasi Bisnis (JAB), 1(1), 1-8.

Schiffman L. G. \& Wisenblit J. L. (2015). Consumer Behavior $\left(11^{\text {th }}\right.$ ed.). England: Pearson Education.

Schiffman, L., O'Cass, A., Paladino, A., \& Carlson, J. (2014). Consumer Behavior (6 ${ }^{\text {th }}$ ed.). Australia: Pearson Australia.

Sekaran, U. \& Bougie, R. (2016). Research Methods for Business: A Skill-Building Approach (6 $6^{\text {th }}$ ed.). New York: John Wiley \& Sons Ltd.

Shahroodi, H. M., Kaviani, H. \& Abasian, M. R. (2015). Evaluating the Effect of Brand Equity on Consumer Satisfaction and Brand Loyalty in Large Retails of the Mazandaran Provine (Case Study: Food Products Industry). European Online Journal of Natural and Social Sciences, 4(1).

Strom, P. S. \& Strom, R. D. (2009). Adolescents in the Internet Age. America: IAP publisher.

Sugandhy, C., Odelia, G. \& Nugroho, A. (2016). Analisa Pengaruh Kualitas Layanan Terhadap Loyalitas Pelanggan di Restoran X Surabaya. Jurnal Hospitality dan Manajemen Jasa, 4(1), 89-102.

Susanty, A. \& Kenny, E. (2015). The Relationship between Brand Equity, Customer Satisfaction, and Brand Loyalty on Coffee Shop: Study of Excelso and Starbucks. Semarang: Asean Marketing Journal, 7(1), 14-27.

Tumbol, W. J. N., Poputra, A. T. \& Runtu, T. (2014). Analisis dengan Menggunakan Informasi Akuntansi Diferensial Dalam Pengambilan Keputusan Membeli atau 
Membuat Sendiri Bakso Pada Bakso Pasuruan. Manado: Jurnal EMBA, 2(2), 14401447.

Turkey, O. dan Sengul, S. (2014). Employee Behaviours creating customer satisfaction: Comparative case study on service encounters at a hotel. European Journal of tourism, Hospitality and Recreation, 5(2).

Widjiono, L. M. \& Japarianto, E. (2015). Analisa Pengaruh Self Image Congruity, Retail Service Quality dan Customer Perceived Service Quality terhadap Repurchase Intention dengan Customer Satisfaction sebagai Variabel Invtervenig di Broadway Babershop Surabaya. Jurnal Manajemen Pemasaran 9(1), 35-42. doi:10.9744

Wolf, E. J., Harrington, K. M., Clark, S. L. \& Miller, M. W. (2013). Sample Size Requirements for Structural Equation Models: An Evaluation of Power, Bias and Solution Propriety. US National Library of Medicine National Institutes of Health, 76(6), 913-934.

Yuliani, R. (2017). Analisis Minat Mahasiswa terhadap Peluang Bisnis Waralaba. Journal Entrepreneur dan Entrepreneurship, 4(1-2), 41-48.

Yuriansyah, A. L. (2013). Persepsi Tentang Kualitas Pelayanan, Nilai Produk dan Fasilitas Terhadap Kepuasan Pelanggan. Management Analysis Journal, 2(1), 8-14. 